\title{
Two New Heteropodine Genera from Southern Continental Asia (Araneae: Sparassidae). ${ }^{1}$
}

\author{
Peter Jäger \\ Institut für Zoologie, Johannes Gutenberg-Universität, Saarstraße 22, 55099 Mainz, Germany \\ E-mail: jaegp000@ mail.uni-mainz.de
}

\begin{abstract}
Two new genera of the subfamily Heteropodinae (Araneae: Sparassidae) are described from southern continental Asia: Pseudopoda gen. nov. and Bhutaniella gen. nov. Type species are designated and described: Pseudopoda prompta (O.P.-Cambridge 1885) COMB. NOV. and Bhutaniella hillyardi sp. nov. The following species, originally described as Heteropoda spp., are included in Pseudopoda gen. nov.: P. casaria (Simon 1897) COMB. NOV., $P$. exigua (Fox 1938) COMB. NOV., P. exiguoides (Song \& Zhu 1999) COMB. NOV., $P$. grahami (Fox 1936) COMB. NOV., P. lushanensis (Wang 1990) COMB. NOV., P. virgata (Fox 1936) COMB. NOV., P. zhangmuensis (Hu \& Li 1983) COMB. NOV., P. zhejiangensis (Zhang \& Kim 1996) COMB. NOV. The following species, originally described as Heteropoda species, is included in Bhutaniella gen. nov: B. sikkimensis (Gravely 1931) COMB. NOV. Species of both genera seem to inhabit only higher altitudes ( $>1000$ meter above sea-level).
\end{abstract}

Key words - Heteropodinae, taxonomy, new genera, Asia

\section{Introduction}

Asian huntsman spiders (Araneae: Sparassidae) have been poorly investigated. Since Simon's revisions $(1880,1897$ a) only few results of taxonomical research on this group in Asia have been published (e.g. Gravely 1931; Sethi \& Tikader 1988; Tikader \& Sethi 1990).

In the framework of a doctoral thesis, mainly based on the substantial collections of J. Martens from Nepal, the author was able to study many species from Asia. During examination of this and additional material from international museums as well as from private collections (C. Deeleman, P. Schwendinger), several species formerly described under the genus Heteropoda Latreille 1804 were recognized as non-congeneric. Heteropoda was used as collecting-genus until recent times by taxonomical authors. This genus is considered a polyphyletic group, from which Sinopoda was separated and described by Jäger (1999). Two new Sinopoda species were recently described by Jäger \& Ono (2000).

This paper continues the revisionary work on the subfamily Heteropodinae. Two new genera will be described. Though more than 50 undescribed species belonging to Pseudopoda gen. nov. and four undescribed species belonging to Bhutaniella gen. nov. were recognized at present, only type species will be designated and described in this paper. A revision and description of further species will be published later.

All specimens are preserved in $70 \%$ ethanol. Epigyna were dissected and cleared

\footnotetext{
${ }^{1}$ Results of the Himalaya Expeditions of J. Martens, No. 231. -No. 230 (Bot. J. Linnean Soc. 133: 61100, 2000). -J. M. sponsored by Deutscher Akademischer Austauschdienst and Deutsche Forschungsgemeinschaft.
} 
afterwards with $96 \%$ lactic acid for a few minutes. In drawings hairs are omitted (except for male palpal spines). A schematic course of the female internal duct-system is proposed: an open circle represents the copulatory orifice, an arrow the end of the fertilization duct, directed to the uterus externus. Spine notation follows Davies (1994). The term "spine-patches" is used for dark femoral spots, from which spines arise. Total text of label of each examined specimen is cited. In similar labels of consecutive specimens only the differences are given, repeated text is represented by three full stops. Comments are added in brackets. Measurements are in millimeters.

\section{Material and Methods}

Abbreviations used in this paper: AP - anterior width of carapace, ALE - anterior lateral eyes, AME - anterior median eyes, $\mathrm{CH}$ - height of clypeus, $\mathrm{Cx}-\mathrm{coxa}, \mathrm{Fe}-$ Femur, mm - millimetres, Mt - metatarsus, OL - abdomen length, OW - abdomen width, Pa - patella, PH - carapace height, PJ - consecutive number of sparassid specimens, examined by Peter Jäger, PL - carapace length, PLE - posterior lateral eyes, PME - posterior median eyes, Pp - palp, PW - carapace width, RTA - retrolateral tibial apophysis, Ta - tarsus, Ti - tibia, I-IV - legs 1-4.

Collections: CM - Coll. Martens, Mainz (D), MCZ - Museum for Comparative Zoology, Massachusetts (USA), NHM - The Natural History Museum, London (GB), NHMB - Naturhistorisches Museum, Basel (CH), HEC - Hope Entomological Collections, University Museum, Oxford (GB), SMF - Senckenberg-Museum, Frankfurt (D).

\section{Taxonomy}

Pseudopoda gen. nov.

Heteropoda (partim): Gravely 1931, pp. 235, 244f., fig. 9K-O; Hu \& Li 1987, pp. 363, 372, figs. 38-39; Sethi \& Tikader 1988, pp. 9, 15, figs. 46-51; Song et al. 1999, p. 467 f.

Type species. Sarotes promptus O.P.-Cambridge 1885

Etymology. The generic name is an acronym of the prefix pseudo (Greek, means "false") and the second part of the genus name Heteropoda. It was chosen with regard to the similar habitus of species of the new genus to Heteropoda spp. The gender is feminine.

Diagnosis. Male palp with membranous conductor (not sheath-like as in Heteropoda spp.) (Figs. 2-3), embolus at least in its proximal part broadened (not filiform as in Heteropoda spp.), mostly whole embolus broadened and flattened (Fig. 5), tegulum as long as bulb (not smaller as in Bhutaniella gen. nov.) (Fig. 2), RTA arising in a mesial or basal position (not in a distal position as in Heteropoda spp.) (Fig. 2).

Females epigynum with lateral lobes (and mostly copulatory ducts) rising distinctly beyond epigastric furrow posteriad (Figs. 9, 12-15) and covering median septum (in most Heteropoda spp. median septum visible).

Description. Small to large representatives $(5-27 \mathrm{~mm})$ of the subfamily Heteropodinae (characters see Jäger 1998).

Color: Yellow, yellow-brown or dark red-brown with dark pattern. Femora with spine patches. Abdomen dorsally mostly with bright transversal band in the posterior half, abdomen ventrally mostly with dark patch in front of the spinnerets.

Habitat: Leaf litter, bark of trees, under stones and logs.

Further species included in Pseudopoda gen. nov.. P. casaria (Simon 1897) 
COMB. NOV., P. exigua (Fox 1938) COMB. NOV., P. exiguoides (Song \& Zhu 1999) COMB. NOV., P. grahami (Fox 1936) COMB. NOV., P. lushanensis (Wang 1990) COMB. NOV., P. virgata (Fox 1936) COMB. NOV., P. zhangmuensis (Hu \& Li 1983) COMB. NOV., P. zhejiangensis (Zhang \& Kim 1996) COMB. NOV.

Distribution. Pakistan, Nepal, N-India, Bhutan, Myanmar, Thailand, S-China (in the East to Zhejiang Prov.); most likely, also in northern parts of Vietnam and Laos. Species of the new genus seem to occur only in higher altitudes ( $>1000$ meter above sea-level).

Note. The author examined more than 50 further undescribed species, which belong to Pseudopoda gen. n. and which are included in the information given in diagnosis, description and distribution range.

\section{Pseudopoda prompta (O.P.-Cambridge 1885) COMB. NOV. (Figs. 1-15)}

Sarotes promptus O.P.-Cambridge 1885, p. 71 (1 female lectotype, PJ 1247, with label: Sarotes promptus O.P.-C., Lectotype, 2nd Yarkand Mission, 1 우, Loan 3964; Murree, Bottle 1323. 3 female paralectotypes, PJ 1248-1250, with label: ...3 우 우 paratypes...11.06.-14.07.1873, Bottle 1323. Examined) HEC 1323.

Heteropoda smythiesi Simon 1897b, pp. 253, 259 (2 male syntypes, with label: Clubionidae - Heteropoda smythiesi E.S., 18.700, Dekkan/18700/Types. Examined). MNHN 18700. 1 male (PJ 1198: intact) herewith designated as lectotype, 1 male (PJ 1199: left palp dissected., prosoma damaged on the left side) as paralectotype; Pocock 1900, pp. 259, 262; Strand 1909, p. 28; Gravely 1931, pp. 248, 256. SYN. NOV.

Heteropoda prompta: Pocock 1900, pp. 259, 261; Gravely 1931 (partim), pp. 248, 256; Sethi \& Tikader 1988 (partim), p. 15, figs. 46-51; Marusik 1993, p. 457 (designated lectotype and paralectotypes).

Further material examined. 2 万ु $\sigma^{7}$ (PJ 984, 985, with label: 1899.8.16.20-22, Heteropoda smythiesi Sim. Konain, Himalayas, 7,800 ft. J. Gleadow/Konain, 7,800 ft./99.8.16.20-22), 1 ऽ (PJ 1000, with label: BM 1900.2.5.32-5, Heteropoda smythiesi Sim., Indian Himalaya, Dehra (F. Gleadow)/Thans [?] (Dehra), F. Gleadow/Lachiwala (Dehra), F. Gleadow), 7 우 우 (PJ 1259-1265, with label: Heteropoda casaria Sim. (= prompta O.P.C.), Mundali (8000ft.), F. Gleadow, BM 1899.8.16.8.17), 1 우 (PJ 999, with label: Heteropodidae, N.W.Himalayas, 22.VII.1924, CEC Fischer, Det. IMH), 1 우 (PJ 1235, with label: 99.8.16.2.7., Konain, Himalaya/Heteropoda prompta, Cambridge, F. H. Gravely det. 1931) all NHM. $4 \sigma^{\top} \sigma^{\nearrow}, 1$ 우 (PJ 212-214+220/221, with label: Pakistan, Murree, 3355'N, 7326'E, $7500 \mathrm{ft}$., 29. VI.1967, Coll.: B. L. Haines) all MCZ. 1 万ٓ (only palp, PJ 1197, with label: Heteropoda smythiesi Sim., $\sigma^{7}$, Palpe, Masuri/104 c. St/Milke [?] von Stuttgart/MNHN Paris, sep. together with types of $H$. smythiesi) MNHN.

Diagnosis. Closely related to P. casaria (Simon 1897) COMB. NOV., but at least males generally smaller ( $\sigma^{\nearrow} \sigma^{7} 7.6^{-10.1}$, 우 우 9.6-15.0; in comparison $P$. casaria: $\sigma^{\nearrow} \sigma^{\nearrow}$ $10.6-14.5 \mathrm{~mm}$, 우 우 10.7-13.3mm) and with distinct differences in genital characters: male palp with apical loop of embolus proximad in lateral view (ventrad in P. casaria) (Fig.

Table 1. Measurements of palp and legs of male Pseudopoda prompta (O.P.Cambridge, 1885) COMB. NOV. (in mm).

\begin{tabular}{lcccccc}
\hline$\sigma^{\top}$ & $\mathrm{Fe}$ & $\mathrm{Pa}$ & $\mathrm{Ti}$ & $\mathrm{Mt}$ & $\mathrm{Ta}$ & Total \\
\hline Pp & $1.7-2.6$ & $0.7-1.1$ & $1.0-1.4$ & & $2.1-2.9$ & $5.5-7.5$ \\
I & $4.2-5.5$ & $1.9-2.5$ & $4.1-5.6$ & $3.8-5.3$ & $1.5-1.8$ & $15.5-20.7$ \\
II & $4.5-5.9$ & $2.0-2.5$ & $4.4-6.0$ & $4.0-5.4$ & $1.5-1.8$ & $16.4-21.4$ \\
III & $3.8-5.3$ & $1.5-2.1$ & $3.3-4.9$ & $3.1-4.3$ & $1.3-1.6$ & $13.0-18.2$ \\
IV & $4.2-5.9$ & $1.4-2.1$ & $3.5-5.2$ & $3.9-5.4$ & $1.4-1.8$ & $14.4-20.4$ \\
\hline
\end{tabular}




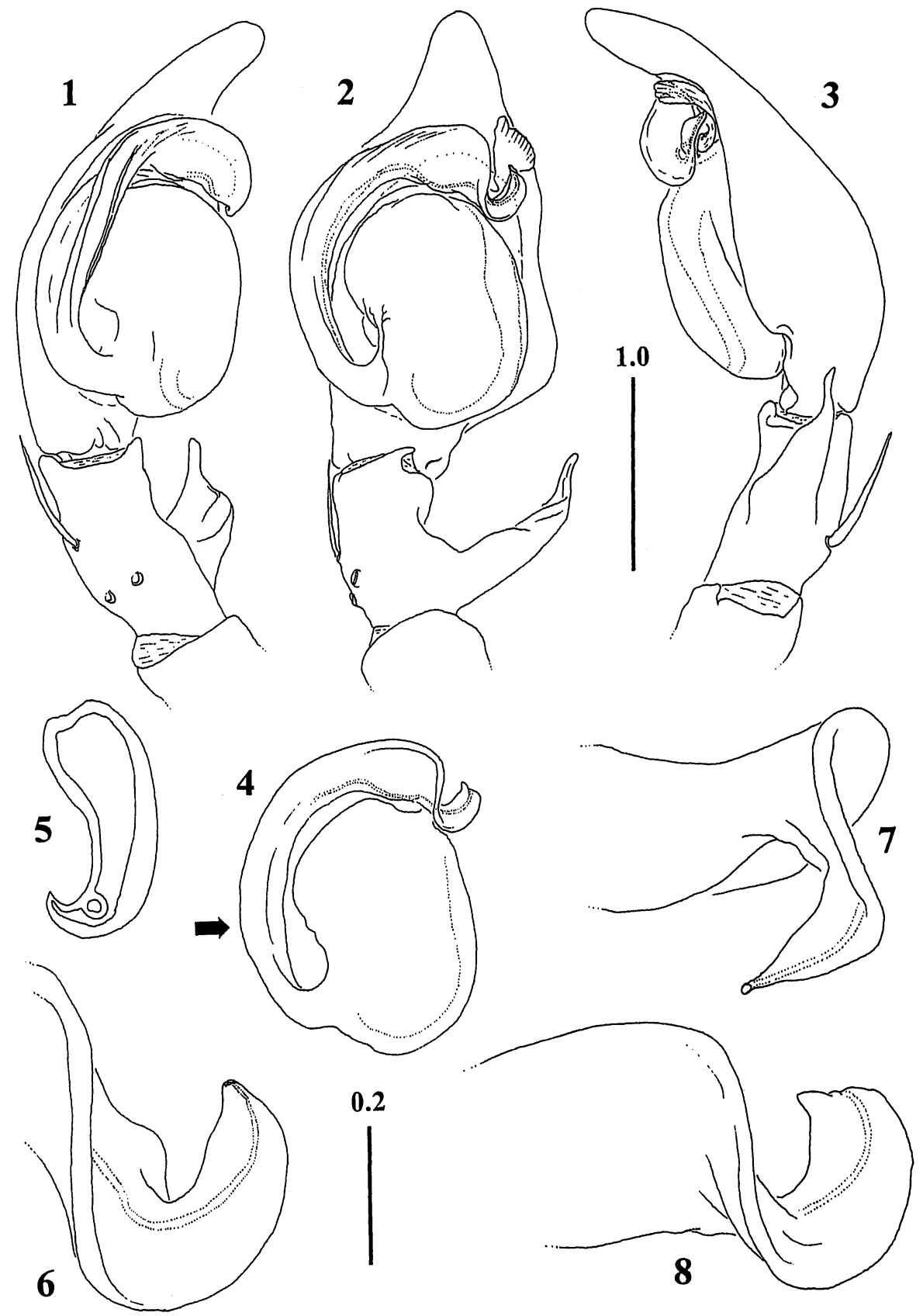

Figs. 1-8. Pseudopoda prompta (O.P.-Cambridge, 1885) COMB. NOV.: 1-3, 6, male from Konain, Himalayas (PJ 984); 4-5, 7-8, male from Murree, Pakistan (PJ 212). $1-3$, male palp (1 prolateral view, 2 ventral view, 3 retrolateral view); 4 , male tegulum and embolus, ventral view; 5 cross section through male embolus (see arrow in Fig. 4); 6-8, tip of male embolus (6 ventral view, 7 distal view, 8 proximo-ventral view). (Scales in $\mathrm{mm}$ ) 

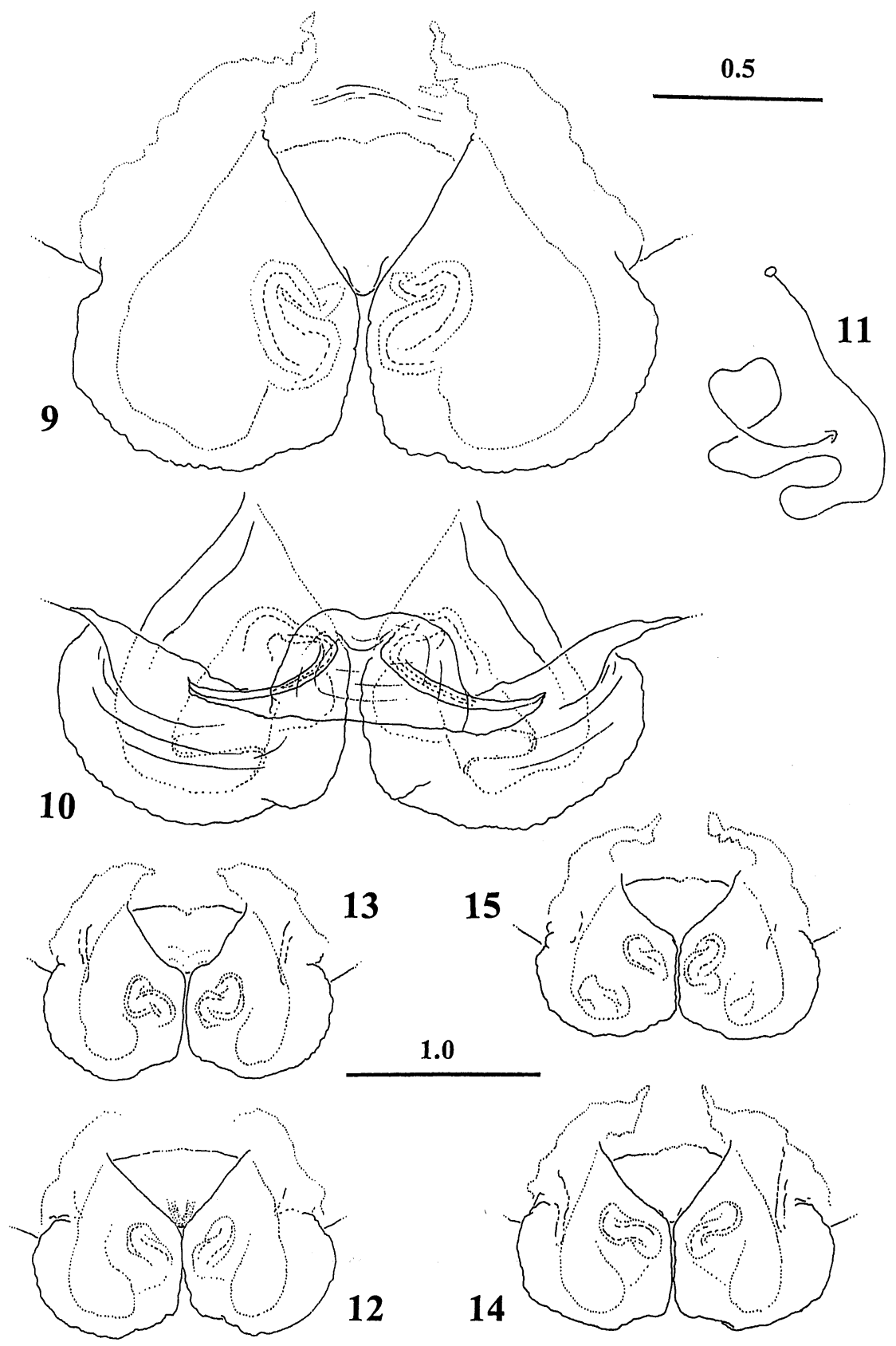

Figs. 9-15. Pseudopoda prompta (O.P.-Cambridge, 1885) COMB. NOV.: 9-11, female from Murree, Pakistan (PJ 221); 12, female lectotype from Murree, Pakistan (HEC 1323); 13-15, female paralectotypes from Murree, Pakistan (HEC 1323). —— 9, 12-15, female epigynum, ventral view; 10, female vulva, dorsal view; 11 schematic course of female internal ducts, dorsal view. (Scales in $\mathrm{mm}$ ) 
3), tip of embolus pointed (Figs. 6-7), sperm-duct marginally at retrolateral margin of tegulum (in $P$. casaria submarginally) (Figs. 2, 4), RTA pointed regularly (without distinct bend as in P. casaria) (Fig. 3). Female vulva with loops of copulatory ducts s-shaped, open to the median line (in P. casaria open to lateral margin) (Figs. 9,12-15).

Redescription. Male. PL 3.6-5.1, PW 3.5-4.5, AP 1.9-2.6, PH 1.0-1.5, OL 4.0-5.5, OW 2.5-3.2. Eye measurements and interdistances: AME 0.15-0.22, ALE 0.30-0.36, PME 0.22-0.29, PLE 0.30-0.32, AME-AME 0.11-0.19, AME-ALE 0.03-0.07, PMEPME 0.21-0.29, PME-PLE 0.29-0.42, AME-PME 0.32-0.36, ALE-PLE 0.29-0.38, CH AME 0.23-0.31, CH ALE 0.19-0.28.

Leg formula: 2143. Spination: Pp 131,0(1)01,2101, Fe I-III 323, IV 33(2)1, Pa (variable, different states: 101, 100, 001, 000), Ti 2026/2126, Mt I-II 1014, III 302(1)4, IV 3036. Measurements of palp and legs as in Table 1. Heavy, semi-circled embolus, arising in a 7.30-o'clock-position (Figs. 1-4), embolus flattened, with two tubuliform cavities, a narrow sperm duct and a large one, which is connected with the tegular cavity (Fig. 5).

Color: Pale yellow (PJ 984,985,1000) to yellow-brown (PJ 1198,1199) with indistinct dark pattern. Prosoma with median and lateral bands, these running together at the darkened head region and behind the fovea. Sternum with only few spots. Fe with distinct spine-patches and less distinct, mainly ventral spots. Abdomen with darker patch above heart, in the posterior half with indistinct transverse bands, laterally mottled, ventrally with broad dark median band.

Female. PL 4.4-5.2, PW 4.0-4.9, AP 2.7-3.2, PH 1.3-1.9, OL 5.1-9.8, OW 3.5-7.2. Eye measurements and interdistances: AME 0.21-0.23, ALE 0.34-0.38, PME 0.24-0.28, PLE 0.33-0.36, AME-AME 0.18-0.22, AME-ALE 0.07-0.10, PME-PME 0.31-0.38, PME-PLE 0.39-0.48, AME-PME 0.35-0.43, ALE-PLE 0.36-0.46, CH AME 0.31-0.35, CH ALE 0.21-0.31.

Leg formula: 2143(2413; $\mathrm{n}=1)$. Spination: Pp 131,001, 2121,1013(4), Fe I 323 II 323(2), III 323(2), IV 331, Pa I-III 001(0), IV 000, Ti 2026 (II 20(1)26; n=1), Mt I 1(0) 014, II 1(2)014, III 302(1)4, IV 3036. Measurements of palp and legs as in Table 2. Palpal claw with 5-6 teeth. Median epigyneal field triangle-shaped, anterior bands of epigyneal field mostly present, short; additional to loops of copulatory ducts their posterior part appearing as dark patch in uncleared vulvae (Figs. 9, 12-15).

Color. As in male, but generally more distinct. Coxae with some spots, partly darkened (if so, with bright basal patch). Abdomen ventrally with distinct median band (may be indistinct in pale specimens).

Biology. According to the pale specimens, it cannot be excluded that at least some populations are cavernicolous. Fresh material is necessary to confirm the differences in the coloration.

Distribution. Pakistan (Murree), NW-India (Dehra Dun, Konain, Mundali,

Table 2. Measurements of palp and legs of female Pseudopoda prompta (O.P.Cambridge, 1885) COMB. NOV. (in mm).

\begin{tabular}{lcccccc}
\hline 우 & $\mathrm{Fe}$ & $\mathrm{Pa}$ & $\mathrm{Ti}$ & $\mathrm{Mt}$ & $\mathrm{Ta}$ & Total \\
\hline $\mathrm{Pp}$ & $1.6-2.0$ & $1.0-1.1$ & $1.3-1.5$ & & $1.9-2.2$ & $6.0-6.7$ \\
I & $4.0-4.7$ & $2.0-2.4$ & $3.7-4.4$ & $3.4-4.1$ & $1.3-1.5$ & $14.6-17.0$ \\
II & $4.4-5.2$ & $2.1-2.5$ & $4.1-4.8$ & $3.6-4.3$ & $1.4-1.5$ & $15.7-18.2$ \\
III & $3.9-4.5$ & $1.7-2.1$ & $3.2-3.8$ & $2.8-3.3$ & $1.2-1.4$ & $12.9-14.8$ \\
IV & $4.3-5.0$ & $1.7-2.0$ & $3.5-4.1$ & $3.5-4.2$ & $1.3-1.5$ & $14.6-16.7$ \\
\hline
\end{tabular}


Masuri [lapsus?]).

Note. Simon (1897b) named "Dekkan (Smythies)" as type locality for the syntypes of Heteropoda smythiesi. Pocock (1900) stated in a foot-note: "no doubt an error for Dehra". Populations in the mountains Dekkan cannot be excluded theoretically. The known distribution of related species of the new genus let suggest that $P$. prompta occurs only in the S-Himalayan.

Relationships. As stated in diagnosis this species and $P$. casaria are closely related to each other. Syntopic population and the consistency of the differences point to the validity of both species. Both species constitute a group, which is characterised by the special genital characters (especially loop at the tip of embolus in male palp, Figs. 6-8; ventral s-shaped loops of ducts in female vulva, Figs. 9, 12-15) and the distinct western distribution.

\section{Bhutaniella gen. nov.}

Heteropoda (partim): Gravely 1931, pp. 235, 243, fig. 9J; Sethi \& Tikader 1988, pp. 9, 27, figs. 124-129.

Type species. Bhutaniella hillyardi sp. nov.

Etymology. Generic name is derived from the country Bhutan. The gender is feminine.

Diagnosis. Male palp with complex embolus (Figs. 16-18), tip of embolus with short embolic apophysis which parallel to embolus (see EA in Fig. 18), tegulum present only in proximal half of bulb (not with larger tegulum as in Sinopoda spp., Pseudopoda gen. n. spp. or Heteropoda spp.), RTA arising in a mesal to proximal position (not in a distal position as in Heteropoda spp.).

Females epigynum with lateral lobes dividing median septum; lateral lobes and copulatory ducts rising only slightly beyond epigastric furrow, epigyneal ledges present (as in Sinopoda spp.), lobal pockets running along epigyneal ledges which mainly longitudinal (see X in Fig. 20) (transversally in Sinopoda spp.).

Description. Small to median representatives $(5-14 \mathrm{~mm})$ of the subfamily Heteropodinae (characters see in Jäger 1998). Male palp with conductor strongly reduced, mostly hidden behind embolus (see $\mathrm{C}$ in Fig. 16). In some species, female vulva hidden behind an integument covering internal ducts, vulva with genital pockets (see GP in Figs. 20-21).

Color. Similar to some Pseudopoda spp.: Yellowish, prosoma with dark pattern (as in Fig. 23). Femora mostly with spots and with larger spine-patches. Abdomen ventrally with dark median line and/or dark patch in front of the spinnerets.

Further species included in Bhutaniella gen. nov.. B. sikkimensis (Gravely 1931) COMB. NOV.

Distribution. E-Nepal, Sikkim, Darjeeling, W-Bhutan.

Relationships. Most likely related to the genus Sinopoda, which possesses also lobal pockets in females and a distal embolic apophysis in males. Both genera are vicarious with each other.

Note. The author examined four further undescribed species, which belong to Bhutaniella gen. nov. and which are included in the information given in diagnosis, description and distribution range. 


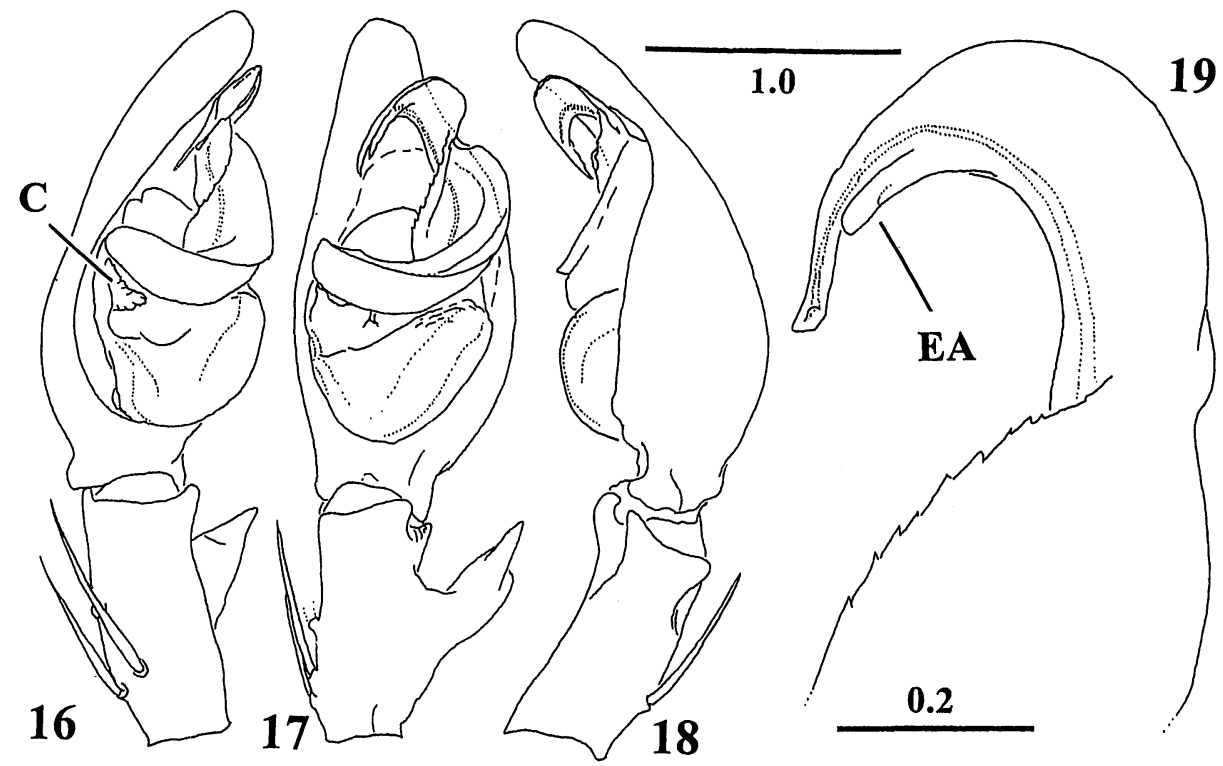

Figs. 16-19. Bhutaniella hillyardi sp. nov.: male holotype from Arun valley, Nepal (PJ 957); - 16-18, male palp (16 prolateral view, 17 ventral view, 18 retrolateral view); 19, tip of male embolus, ventral view. C - membranous remnant of conductor; EA embolic apophysis (Scales in $\mathrm{mm}$ )

Bhutaniella hillyardi sp. nov.

(Figs. 16-22)

Type material. Male holotype (PJ 957, with label: 412, Sankhua Sabha Distr., Arun valley betw. Mure \& Hurure, 2050-2150 m, 9-17 Juni 1988, Martens \& Schawaller leg.), 1 female paratype (PJ 958, dito), all CM, will be deposited in SMF.

Etymology. Dedicated to Dr. Paul Hillyard for his work as curator of the Natural History Museum, London (noun in genitive).

Diagnosis. Male palp with embolus distally flattened and broadened, turned around its length axis (Figs. 16-18), RTA short, with two apices (Fig. 18). Female vulva with copulatory ducts freely visible, without integument, directed latero-mediad (Fig. 21).

Description. Male. PL 4.0, PW 3.6, AP 1.9, PH 1.5, OL 4.1, OW 2.6. Eye measurements and interdistances: AME 0.20, ALE 0.32, PME 0.27, PLE 0.31, AMEAME 0.13, AME-ALE 0.04, PME-PME 0.16, PME-PLE 0.30, AME-PME 0.35, ALEPLE 0.29, CH AME 0.43, CH ALE 0.33.

Leg formula: 2413. Spination: Pp 131,101,2101, Fe I-III 323, IV 321, Pa 101, Ti III 2026, III-IV 2126, Mt I-II 1014, III 2024, IV 3036. Measurements of palp and legs as in Table 3. Embolus distally with embolic apophysis (see EA in Fig. 19), edge between distal and basal part of embolus serrated, sperm duct without loop (Figs. 17,19), conductor visible at the base of embolus in prolateral view (see $\mathrm{C}$ in Fig. 16).

Color: Red-yellowish with distinct brown pattern. Prosoma with radial bands of small spots (as in Fig. 23). Sternum and coxae pale yellow, without pattern. Femora 


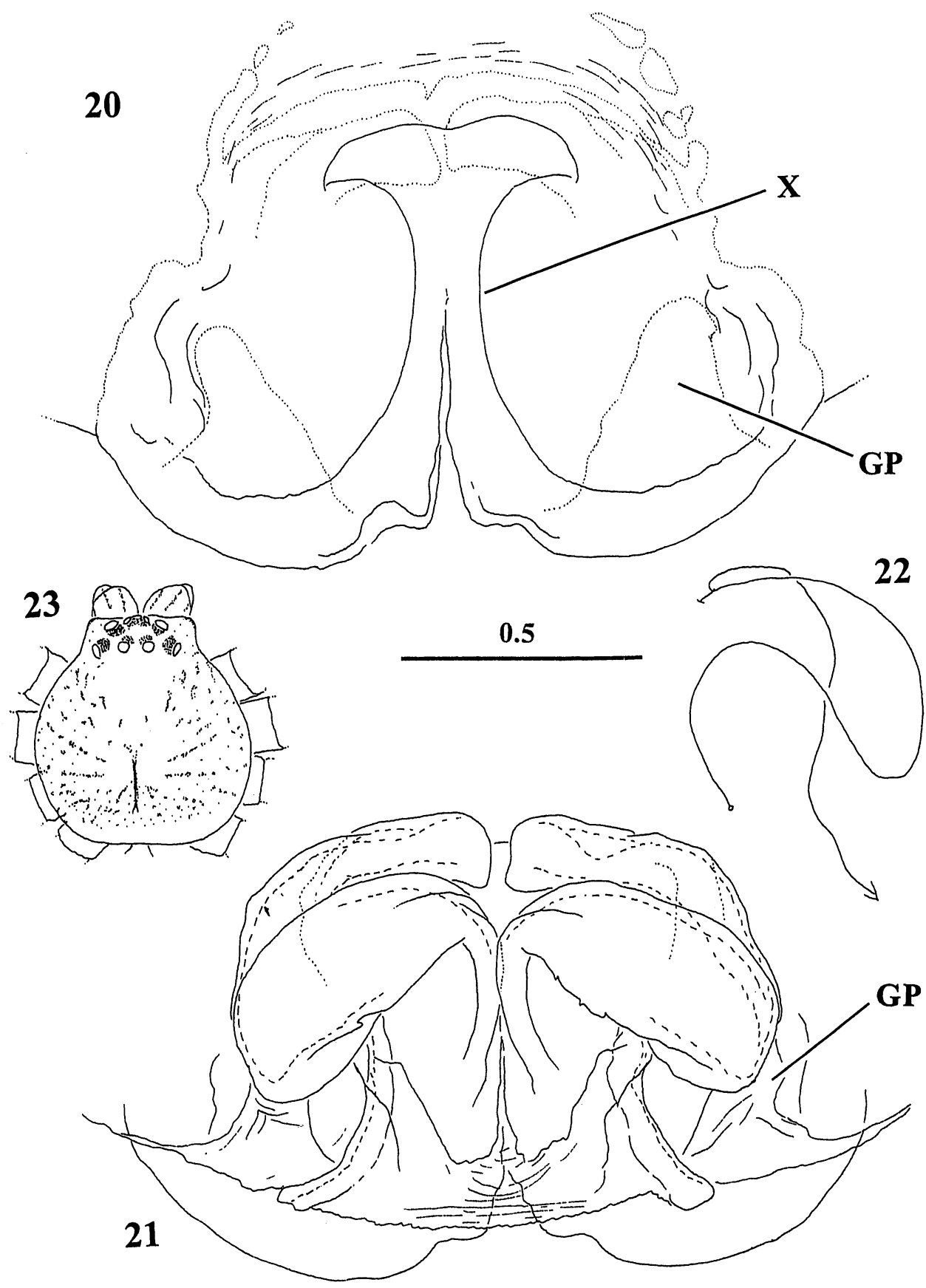

Figs. 20-23. Bhutaniella hillyardi sp. nov.: female paratype from Arun valley, Nepal (PJ 958) (20-22) and Bhutaniella sp. (23) - 20, female epigynum, ventral view; 21, female vulva, dorsal view; 22 , schematic course of female internal ducts, dorsal view; 23 , prosomal pattern. GP - genital pockets, $\mathrm{X}$ - epigyneal ledges (Scale in mm; 23 not to scale) 
Table 3. Measurements of palp and legs of male and female Bhutaniella hillyardi sp. n., male holotype and female paratype (in $\mathrm{mm}$ ).

\begin{tabular}{|c|c|c|c|c|c|c|c|c|c|c|c|c|c|}
\hline $0^{7}$ & $\mathrm{Fe}$ & $\mathrm{Pa}$ & $\mathrm{Ti}$ & Mt & $\mathrm{Ta}$ & Total & 우 & $\mathrm{Fe}$ & - $\mathrm{Pa}$ & $\mathrm{Ti}$ & Mt & $\mathrm{Ta}$ & Total \\
\hline $\mathrm{Pp}$ & 1.7 & 0.8 & 1.0 & & 2.1 & 5.6 & & 1.8 & 0.9 & 1.2 & & 2.0 & 5.9 \\
\hline I & 4.5 & 1.8 & 4.7 & 4.0 & 1.4 & 16.4 & & 4.5 & 2.0 & 4.2 & 3.7 & 1.4 & 15.8 \\
\hline II & 5.0 & 2.0 & 5.2. & 4.4 & 1.6 & 18.2 & & 4.8 & 2.0 & 4.4 & 3.8 & 1.4 & 16.4 \\
\hline III & 4.2 & 1.5 & 4.0 & 3.0 & 1.2 & 13.9 & & 4.3 & 1.5 & 3.6 & 3.1 & 1.2 & 13.7 \\
\hline IV & 4.8 & 1.5 & 4.5 & 5.0 & 1.5 & 17.3 & & 5.0 & 1.7 & 3.9 & $4.3^{\circ}$ & 1.4 & 16.3 \\
\hline
\end{tabular}

ventrally with many small spots, dorsally with few spots and larger spine-patches. Abdomen dorsally with bright anterior half, sigillae with dark margin; in posterior half with irregular markings; ventrally with dark median longitudinal band, within this a darker line; in front of the spinnerets with dark patch.

Female PL 4.5, PW 4.1, AP 2.4, PH 2.0, OL 6.7, OW 5.0. Eye measurements and interdistances: AME 0.22, ALE 0.35, PME 0.29, PLE 0.35, AME-AME 0.16, AMEALE 0.08, PME-PME 0.21, PME-PLE 0.41, AME-PME 0.38, ALE-PLE 0.34, CH AME 0.45, CH ALE 0.38.

Leg formula: 2413. Spination: Pp 131, 1(0)01, 2121, 1014, Fe I-III 323, IV 321, Pa 101, Ti I-II 2026, III 2126, IV 2026, Mt I-II 1014, III 2024, IV 3036. Measurements of palp and legs as in Table 3. Palpal claw with 6 teeth. Epigyneal field in some specimens with anterior bands, these consisting of single patches (Fig. 20). First winding of copulatory ducts broad, latero-caudad, the second winding mediad, without appendix (Figs. 21-22).

Color: As in male.

Distribution. E-Nepal, Sankhua Distr. (Arun Valley: Mure/Hurure).

\section{Acknowledgments}

The author thanks gratefully Prof. Dr. J. Martens (Mainz, Germany) for offering opportunity to study the material and also for his helpful advice. Thanks are also due to Dr. Christa Deeleman (Ossendrecht, Netherlands) and Dr. Peter Schwendinger (Genf, Switzerland) for leaving their material to the author's disposal. Comments to the manuscript by an anonymous reviewer are also acknowledged. This research was supported by a grant of the Land Rheinland-Pfalz (Germany) through the Landesgraduiertenförderungsgesetz. Travels to China were partly financed by the Stifterverband für die Deutsche Wissenschaft (Essen, Germany) and the Freunde der Johannes Gutenberg-Universität (Mainz, Germany).

\section{References}

Davies, V. T. 1994. The huntsman spiders Heteropoda Latreille and Yiinthi gen. nov. (Araneae: Heteropodidae) in Australia. Mem. Queensl. Mus., 35: 75-122.

Gravely, F. H. 1931. Some Indian spiders of the families Ctenidae, Sparassidae, Selenopidae and Clubionidae. Rec. Ind. Mus., 33: 211-282.

Hu, J. L. \& Li, A. H. 1987. The spiders collected from the fields and the forests of Xizang Autonomous Region, China (1). Agricultural Insects, Spiders, Plant Deseases and Weeds of Xizang 1: 315-392.

Jäger, P. 1998. First results of a taxonomic revision of the SE Asian Sparassidae (Araneae). Proceedings of the 17th European Colloquium of Arachnology, Edinburgh, 1997. (P. A. Selden, ed.), Burnham Beeches, Bucks: Bull. British Arach. Soc., pp. 53-59.

Jäger, P. 1999. Sinopoda, a new genus of Heteropodinae (Araneae, Sparassidae) from Asia. J. Arachnol., 27: 19-24.

Jäger, P. \& Ono, H. 2000. The Sparassidae of Japan. I. New species of Olios, Heteropoda and Sinopoda with notes on some known species (Araneae: Sparassidae: Sparassinae and Heteropodinae). Acta 
Arachnol.: 49: 41-60.

Marusik, Y. M. 1993. Re-description of spiders of the families Heteropodidae and Thomisidae (Aranei), described by O.P.-Cambridge from the material of the Second Yarkand Mission. Entomol. Obozr., 72 (2): 456-468. [In Russian]

Pickard-Cambridge, O. 1885. Scientific results of the second Yarkand Mission; based upon the collections and notes of the late Ferdinand Stoliczka, Ph. D. Araneidea. Superintendent of Government, India., 115 pp., Calcutta.

Pocock, R. I. 1900. The fauna of British India including Ceylone and Burma. Arachnida. Second Reprint. 279 pp., New Delhi.

Sethi, V. D. \& Tikader, B. K. 1988. Studies on some giant crab spiders of the family Heteropodidae from India. Rec. Zool. Surv. India, Misc. publ. occas. pap., 93: 1-94.

Simon, E. 1880. Revision de la famille des Sparassidae (Arachnides). Act. Soc. Linn. Bordeaux, 34: 223 -351 .

Simon, E. 1897a. Histoire Naturelle des Araignées. Roret, Paris, 2: 1-192.

Simon, E. 1897b. Materiaux pour servir a la faune arachnologique de l'Asie meridionale. V (1). Arachnides recueillis a Dehra-Dun (N. W. prov.) et dans le Dekkan par M. A. Smythies. Mem. Soc. zool. France, 10: 252-262.

Song, D. X., Zhu, M. S. \& Chen, J. 1999. The Spiders of China. Hebei Sci. Technol. Publ. House, 640 pp., Shijiazhuang.

Strand, E. 1909. Süd- und ostasiatische Spinnen. II. Fam. Clubionidae - Fam. Salticidae. Abh. naturf. Ges. Görlitz., 26: 1-128.

Tikader, B. K. \& Sethi, V. D. 1990. Studies of some giant crab spiders of the family Heteropodidae from India. Part II. Rec. zool. Surv. India, 87: 165-186.

(Received March 15, 2000/Accepted April 15, 2000) 
た。本種は沖縄本島に固有で，石灰洞にのみ発 見される。個体群密度は非常に低い。これまで 雌のみしか採集されておらず，また，雌の外雌 器や交尾口の退化は, 本種が単為生殖をおこな っている可能性を強く示唆する. 本種は洞穴内 での生活に適応的とみられる形質を他にもいく つか備える. 琉球列島の地史に関連して, 洞穴 という生息場所への特化について議論した。

日本産アシダカグモ科, I. ミナミアシダカグモ 属(新称), アシダカグモ属, コアシダカグモ属 (新称)の 4 新種の記載および既知種についての 知見（クモ目：アシダカグモ科：ツユグモ亜科 およびアシダカグモ垔科)（pp. 41-60)

P. Jäger ${ }^{1}$ ・ 小野展嗣 ${ }^{2}$ ('Institut für Zoologie, Johannes Gutenberg-Universität, Germany ; ${ }^{2} \mathbf{T} 169$ -0073 東京都新宿区百人町 3-23-1 国立科学 博物館動物研究部)

日本産アシダカグモ科の Olios [ミナミアシダ カグモ属 (新称) ] の 1 新種, Heteropoda [アシ ダカグモ属］の 1 新種ならびに Sinopoda [コア シダカグモ属 (新称) ] の 2 新種の計 4 新種を以 下のように命名して記載した：Olios japonicus sp. nov. [ニホンミナミアシダカグモ (新称)], Heteropoda simplex sp. nov. [ホソミアシダカグ モ (新称, 細身の意)] Sinopoda okinawana sp. nov. [リュウキュウコアシダカグモ (新称) ], Sinopoda tanikawai sp. nov. [アマミコアシダカ グモ (新称)]. ミナミアシダカグモ属は日本か ら新たに記録された。そのほか, 本科のいくつ かの既知種について若干の分類学的知見と採集 記録を付記し, 日本産の亜科および属の特徴に ついて解説を加えた。

大陸アジア南部からのアシダカグモ亜科（アシ ダカグモ科) の 2 新属（pp. 61-71）

P. Jäger (Institut für Zoologie, Johannes Gutenberg-Universität, Germany)

大陸アジア南部からのアシダカグモ亜科（ア シダカグモ科）の 2 新属Pseudopoda と Bhutaniella を記載した。 それぞれPseudopoda prompta (O. P.-Cambridge 1885) と Bhutaniella hillyardi を模式種として指定し，記載した。 Heteropoda 属として記載されていた次の種は Pseudopoda に転属させた：P. casaria (Simon 1897), P. exigua (Fox 1938), P. exiguoides (Song \& Zhu 1999), P. grahami (Fox 1936), P. lushanensis (Wang 1990), P. virgata (Fox 1936), $P$. zhangmuensis (Hu \& Li 1983), P. zhejiangensis (Zhang \& Kim 1996). また, Heteropoda sikkimensis Gravely 1931 Bhutaniellaに移し た.両属とも分布は標高 $1000 \mathrm{~m}$ 以上の高所に限 られているようである。（和訳：編集委員会）

シベリアとモンゴルからのザトウムシの 2 新種 (1 新属) とウデブトザトゥムシ属の再定義（マ ザトウムシ科）（pp. 73-86）

鶴崎展巨 ${ }^{1}$, A. N. Tchemeris ${ }^{2}, \&$ D. V. Logunov ${ }^{3}$ ( ${ }^{1}$ T680-8551 鳥取市湖山町南 4-101 鳥取大 学教育地域科学部生物学教室; ${ }^{2}$ Dept. Invertebrate Zool., Fac. Biol. \& Soil Sci. Tomsk State University, Tomsk, Russia ; ${ }^{3}$ Zool., Mus., Biol. Instit. Siberian Div. Russ. Acad. of Sci., Novosibirsk, Russia)

シベリアからマザトウムシ科の Acanthomegabunus sibiricus を新属新種として，また， モンゴル南ゴビ地方からウデブトザトウムシ属 の 1 種 Homolophus gobiensis を新種として記載 した. ウデブトザトウムシ属については再定義 を与え, Phalangium pallens Kulczynski を本属 に,また Homolophus potanini を Opilio 属に移 した. Opilio asiaticus Gricenko は Opilio potanini (Simon) の後行異名とした.

シベリア南部からのウデザトウムシScleropilio insolens の再記載とウデザトウムシ属の 改訂 (pp. 87-94)

鶴崎展巨 ${ }^{1}$, A. N. Tchemeris, \& D. V. Logunov ${ }^{3}$ ( ${ }^{1}$ T680-8551 鳥取市湖山町南 4-101 鳥取大 学教育地域科学部生物学教室 ; ${ }^{2}$ Dept. Invertebrate Zool., Fac. Biol. \& Soil Sci. Tomsk State University, Tomsk, Russia ; ${ }^{3}$ Zool. Mus., Biol. Instit. Siberian Div. Russ. Acad. of Sci., Novosibirsk, Russia) 